\title{
Benthic community respiration in areas impacted by the invasive mollusk Crepidula fornicata
}

\author{
Sophie Martin ${ }^{1,2, *}$, Gérard Thouzeau ${ }^{3}$, Marion Richard ${ }^{3}$, Laurent Chauvaud ${ }^{3}$, \\ Frédéric Jean $^{3}{ }^{3}$ Jacques Clavier $^{3}$
}

\author{
${ }^{1}$ Laboratoire d'Océanographie de Villefranche, 06230 Villefranche-sur-Mer, France \\ ${ }^{2}$ Laboratoire d'Océanographie de Villefranche, Université Pierre et Marie Curie, Paris VI, 06234 Villefranche-sur-Mer, France \\ ${ }^{3}$ Laboratoire des Sciences de l'Environment Marin, UMR CNRS 6539, Institut Universitaire Européen de la Mer, \\ Technopôle Brest-Iroise, Place Nicolas Copernic, 29280 Plouzané, France
}

\begin{abstract}
The American slipper limpet Crepidula fornicata L. has been an invasive species in European bays and estuaries since the 1950s and can reach densities up to several thousands of individuals $\mathrm{m}^{-2}$. The objective of this study was to estimate the impact of $C$. fornicata on benthic community metabolism by comparing 2 contrasting sites with high $\left(>1000\right.$ ind. $\left.\mathrm{m}^{-2}\right)$ and low $\left(<200\right.$ ind. $\left.\mathrm{m}^{-2}\right)$ densities in the Bay of Brest (Brittany, France). Measurements of dissolved oxygen (DO) and dissolved inorganic carbon (DIC) fluxes at the water-sediment interface were investigated using benthic chambers. Community respiration (CR) was 1.5- to 3-fold higher at the station with high densities, where it varied from $1.5 \mathrm{mmol} \mathrm{C} \mathrm{m}^{-2} \mathrm{~h}^{-1}$ in winter to $5.9 \mathrm{mmol} \mathrm{C} \mathrm{m}^{-2} \mathrm{~h}^{-1}$ in summer, and, considering $C$. fornicata biomass, from $0.7 \mathrm{mmol} \mathrm{C} \mathrm{g}^{-1} \mathrm{dry} \mathrm{wt} \mathrm{h}^{-1}$ in winter to $3.3 \mathrm{mmol} \mathrm{C} \mathrm{g}^{-1}$ dry wt $\mathrm{h}^{-1}$ in summer. CR was mainly controlled by C. fornicata biomass, temperature, and chl a concentration in the water column. Community respiratory quotients $\left(C R Q=\left|\mathrm{CR}_{\mathrm{DIC}} / \mathrm{CR}_{\mathrm{DO}}\right|\right)$ were 0.74 in winter-spring and 1.38 in summer-autumn. Annual CR averaged $440 \mathrm{~g} \mathrm{C} \mathrm{m}^{-2} \mathrm{yr}^{-1}$ at the highly colonized station, and $180 \mathrm{~g} \mathrm{C} \mathrm{m}^{-2} \mathrm{yr}^{-1}$ at the station displaying low density of $C$. fornicata. The estimated annual CR for an average density of 260 ind. $\mathrm{m}^{-2}$ in the whole Bay of Brest was $220 \mathrm{~g} \mathrm{C} \mathrm{m}^{-2}$ $\mathrm{yr}^{-1}$, which was higher than the carbon production of the overlying phytoplankton and microphytobenthos in the bay. C. fornicata is thus considered a source of carbon influencing partial pressure of $\mathrm{CO}_{2}$ in seawater and favoring $\mathrm{CO}_{2}$ effluxes to the atmosphere.
\end{abstract}

KEY WORDS: Benthic community respiration - Carbon cycling - Invasive species - Crepidula fornicata $\cdot$ Water-sediment interface

\section{INTRODUCTION}

The ecological impact of aquatic invasive species is a growing concern for coastal zone management and conservation (Grosholz 2002). The multiple ecological effects of invaders and their impact on native species populations and related ecosystems have been widely documented (Mack et al. 2000, Stachowicz \& Byrnes 2006). At the ecosystem level, invasive species influence the processes determining carbon and nutrient cycling (Arnott \& Vanni 1996, Ragueneau et al. 2002, Martin et al. 2006). In aquatic environments, mollusks such as Dreissena polymorpha, Ruditapes philippinarum, Potamocorbula amurensis, and Crepidula fornicata are among the most common invaders (Carlton et al. 1990, Mills et al. 1993, Blanchard 1997, Chauvaud et al. 2003). These species are very active suspension feeders, and their dense assemblages may exert a strong influence on suspended particulate matter (Dame 1996). The feeding activity of filter feeders results in the packaging of suspended material into feces and pseudofeces that settle to the bottom, diverting primary production and energy flow from planktonic to benthic food webs and increasing the release of dissolved end products of organic matter mineralization from the bottom (Arnott \& Vanni 1996). 
In addition to stimulating benthic bacterial respiration through biodeposition, suspension feeders also release carbon through their own metabolism (Chauvaud et al. 2003, Martin et al. 2006). In shallow coastal waters, benthic communities dominated by dense populations of suspension feeders are important zones for carbon cycling and may dominate ecosystem processes and metabolism (Middelburg et al. 2005).

The American slipper limpet Crepidula fornicata L. was mainly introduced in Europe in the late 1940s early 1950s and has rapidly invaded coastal waters from the Mediterranean to the Baltic Sea. At present, C. fornicata proliferates in bays and estuaries, reaching several thousands of individuals $\mathrm{m}^{-2}$ (Blanchard 1997). In the Bay of Brest, France, C. fornicata colonizes more than half of the benthic surface area (Guérin 2004) and induces both economic and

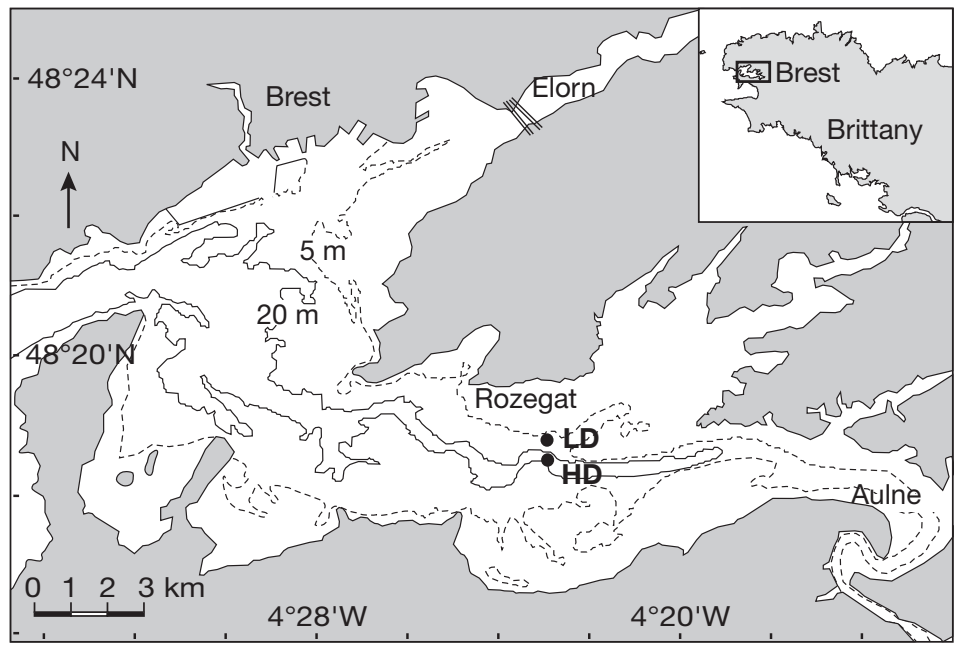

Fig. 1. Locations of the experimental stations (HD, high Crepidula fornicata density; LD, low C. fornicata density) at the Rozegat site in the Bay of Brest, France

ecological consequences through disturbance of mollusk cultures and fisheries, and shifts in benthic community species composition and trophic structure (Chauvaud et al. 2000, Thouzeau et al. 2000). In affected areas, the high respiration rate of $C$. fornicata enhances the partial pressure of $\mathrm{CO}_{2}\left(p \mathrm{CO}_{2}\right)$ in seawater and subsequent $\mathrm{CO}_{2}$ effluxes to the atmosphere (Martin et al. 2006). C. fornicata also influences carbon fluxes in the benthic community by stimulating the bacterial decomposition processes through its high biodeposition (Chauvaud et al. 2000, Ragueneau et al. 2002, 2005). Increased benthic respiration and mineralization can decrease dissolved oxygen (DO) concentration, inducing shifts to hypoxic conditions in sediments (Stenton-Dozey et al. 2001). However, the impact of $C$. fornicata on DO and carbon fluxes has never been assessed at the community level. The objective of this study was to estimate the effect of the mollusk invasion on community metabolism by comparison of oxygen and carbon fluxes at 2 stations with contrasting densities of $C$. fornicata.

\section{MATERIALS AND METHODS}

Site description. The Bay of Brest is a shallow semienclosed marine ecosystem of $180 \mathrm{~km}^{2}$ located at the extreme west of Brittany, France (Fig. 1). The hydrology of the bay is controlled by tidal forcing and is influenced by the moderate input of 2 rivers (Elorn and Aulne). The bay is a shallow basin $(50 \%$ of its surface is $<5 \mathrm{~m}$ in depth below Chart Datum) with more than half of its benthic surface colonized by Crepidula fornicata (Guérin 2004). The experiments were performed at the Rozegat site, at 2 stations with contrasting C. fornicata densities: $>1000$ ind. $\mathrm{m}^{-2}$ at $\mathrm{Stn}$ HD and $<200$ ind. $\mathrm{m}^{-2}$ at Stn LD. The 2 stations were situated $300 \mathrm{~m}$ apart. The field experiments took place between May 2000 and September 2004 (Table 1) and were carried out from the RV 'Côtes de la Manche'. Average water depth was $20 \mathrm{~m}$ at Stn HD and $10 \mathrm{~m}$ at Stn LD. Temperature, chlorophyll a $(\operatorname{chl} a)$, and DO concentrations in surface waters were provided by the automated MAREL Iroise Station (IUEM-UBO, Observatoire du Domaine Côtier) located in the west of the Bay of Brest. During the sampling period, temperature varied from $8.4^{\circ} \mathrm{C}$ in winter to $18.7^{\circ} \mathrm{C}$ in summer, chl a concentration varied from minima $\left(0.3\right.$ to $\left.0.5 \mathrm{\mu g} \mathrm{l}^{-1}\right)$ in January to maxima (2.7 to $6.4 \mathrm{\mu g} \mathrm{l}^{-1}$ ) in April-May, and DO concentration varied from minima (5.1 to $5.3 \mathrm{ml} \mathrm{l}^{-1}$ ) between August and October to maxima (6.9 to $7.6 \mathrm{ml} \mathrm{l}^{-1}$ ) between March and May in surface waters (Fig. 2).

Field measurements. In situ measurements of fluxes at the water-sediment interface were performed according to Martin et al. (2005). Three replicate opaque benthic chambers were deployed, covering an area of $0.2 \mathrm{~m}^{2}$ and

Table 1. Experimental periods and number of incubations at Stns HD and LD

\begin{tabular}{|llcc|}
\hline Season & Date & HD & LD \\
\hline Winter & February 2004 & 9 & 3 \\
Spring & May to June 2000, May 2001, & 22 & 16 \\
& May 2002 & & \\
Summer & September 2004 & 6 & 6 \\
Autumn & October 2001, October 2002 & 12 & 12 \\
\hline
\end{tabular}


incubating a known volume ( 60 l) of bottom water. A series of incubations was carried out for 120 to $240 \mathrm{~min}$. DO concentration $\left(\mathrm{mg} \mathrm{l}^{-1}\right)$, salinity (in practical salinity units, PSU), temperature $\left({ }^{\circ} \mathrm{C}\right)$, and depth $(\mathrm{m})$ were recorded every minute inside the chambers with YSI 6920 probes. Water samples were collected from the benthic chambers using $450 \mathrm{ml}$ syringes, for $\mathrm{pH}$ and total alkalinity (TA) at the beginning and end of the incubations. Water samples were passed through GF/F filters and poisoned with mercuric chloride (DOE 1994). Fauna enclosed in the chambers was collected by SCUBA divers using an airlift suction sampler at the end of the incubations. Three samples of surface-sediment were collected with cores at Stns LD and HD and frozen for subsequent organic content analysis in May 2000, May 2001, and October 2001.

Sample processing. The $\mathrm{pH}$ (in total scale) was measured immediately on board using a $\mathrm{pH}$ meter (PHM 240, Radiometer) calibrated against buffer solutions (TRIS/HCl and 2-aminopyridine/HCl) in seawater (DOE 1994). TA was measured on $50 \mathrm{ml}$ subsamples using the automatic potentiometric method, with Gran titration (Titrilab TIM 865, Radiometer). The concentration of total dissolved inorganic carbon (DIC) was calculated from $\mathrm{pH}$, TA, temperature, and salinity (Lewis \& Wallace 1998).

Crepidula fornicata individuals were sorted and counted. Shell length was measured $( \pm 0.01 \mathrm{~mm})$, and total dry weight $\left(\mathrm{DW}_{i} \pm 0.001 \mathrm{~g}\right)$ of samples (shells + soft body) was determined after drying at $60^{\circ} \mathrm{C}$ for 72 h. Population structure was established through size frequency histograms (1 $\mathrm{mm}$ intervals). Sediment samples for organic content analysis were dried at $60^{\circ} \mathrm{C}$, weighed, and reweighed after combustion for $4 \mathrm{~h}$ at $450^{\circ} \mathrm{C}$.

Data treatment. DO, DIC, and TA fluxes were calculated by the difference between the initial and final concentrations in the enclosures:

$$
F_{X}=\frac{\Delta x \times V}{s \times \Delta t}
$$

where $F_{X}$ represents community fluxes of $x=\mathrm{DO}$, DIC $\left(\mathrm{mmol} \mathrm{m} \mathrm{m}^{-2} \mathrm{~h}^{-1}\right.$ ), or TA (mequiv. $\left.\mathrm{m}^{-2} \mathrm{~h}^{-1}\right) ; \Delta x$ is the change in the concentration of $x=\mathrm{DO}, \mathrm{DIC}\left(\mathrm{mmol} \mathrm{l}^{-1}\right)$, or TA (mequiv. $\mathrm{l}^{-1}$ ) during the incubation; $V$ is the chamber volume (1); $s$ is the enclosed surface area $\left(\mathrm{m}^{2}\right)$; and $\Delta t$ is the incubation time (h).

Community respiration $\left(\mathrm{CR}, \mathrm{mmol} \mathrm{m} \mathrm{m}^{-2} \mathrm{~h}^{-1}\right)$ was estimated from $\mathrm{DO}$ consumption $\left(\mathrm{CR}_{\mathrm{DO}}=F_{\mathrm{DO}}\right)$, including both aerobic respiration and oxidation of end products of anaerobic metabolism. CR was also measured from DIC release $\left(\mathrm{CR}_{\mathrm{DIC}}\right)$, representing all respiration pathways (aerobic respiration, denitrification, and reduction of manganese, iron, and sulfate; Middelburg et al. 2005). In communities dominated by calcifying organisms, $\mathrm{CR}_{\mathrm{DIC}}$ is usually estimated by subtracting the change in DIC resulting from community net calcification $\left(\mathrm{Ca}^{2+}+2 \mathrm{HCO}_{3}^{-} \rightarrow \mathrm{CaCO}_{3}+\mathrm{CO}_{2}+\mathrm{H}_{2} \mathrm{O} ; \Delta \mathrm{TA}=\right.$ -2 equiv.; Gattuso et al. 1999) from $F_{\text {DIC }}$ using the alkalinity anomaly technique (Chisholm \& Gattuso 1991):

$$
\mathrm{CR}_{\mathrm{DIC}}=F_{\mathrm{DIC}}-1 / 2 F_{\mathrm{TA}}
$$

However, ammonification $\left(\mathrm{NO}_{3}^{-}+2 \mathrm{H}^{+}+\mathrm{H}_{2} \mathrm{O} \rightarrow\right.$ $\mathrm{NH}_{4}{ }^{+}+2 \mathrm{O}_{2}, \Delta \mathrm{TA}=+2$ equiv.) and sulfate reduction $\left(\mathrm{SO}_{4}{ }^{2-}+2 \mathrm{H}^{+} \rightarrow \mathrm{H}_{2} \mathrm{~S}+2 \mathrm{O}_{2} ; \Delta \mathrm{TA}=+2\right.$ equiv.; Gattuso et al. 1999, Middelburg et al. 2005) may significantly alter $F_{\mathrm{TA}}$ in organic matter enriched systems, and, in that case, the simple correction of $F_{\text {DIC }}$ by $F_{\mathrm{TA}}$ cannot be applied. In our study, $\mathrm{CR}_{\text {DIC }}$ was calculated from $F_{\text {DIC }}$ corrected for calcification effects:

$$
\mathrm{CR}_{\text {DIC }}=F_{\text {DIC }}-1 / 2 F_{\text {TAcalc }}
$$

where $F_{\text {TAcalc }}$ is the change in TA from Crepidula fornicata calcification (mequiv. $\mathrm{m}^{-2} \mathrm{~h}^{-1}$ ). Indeed, C. fornicata is the predominant calcifying organism in the
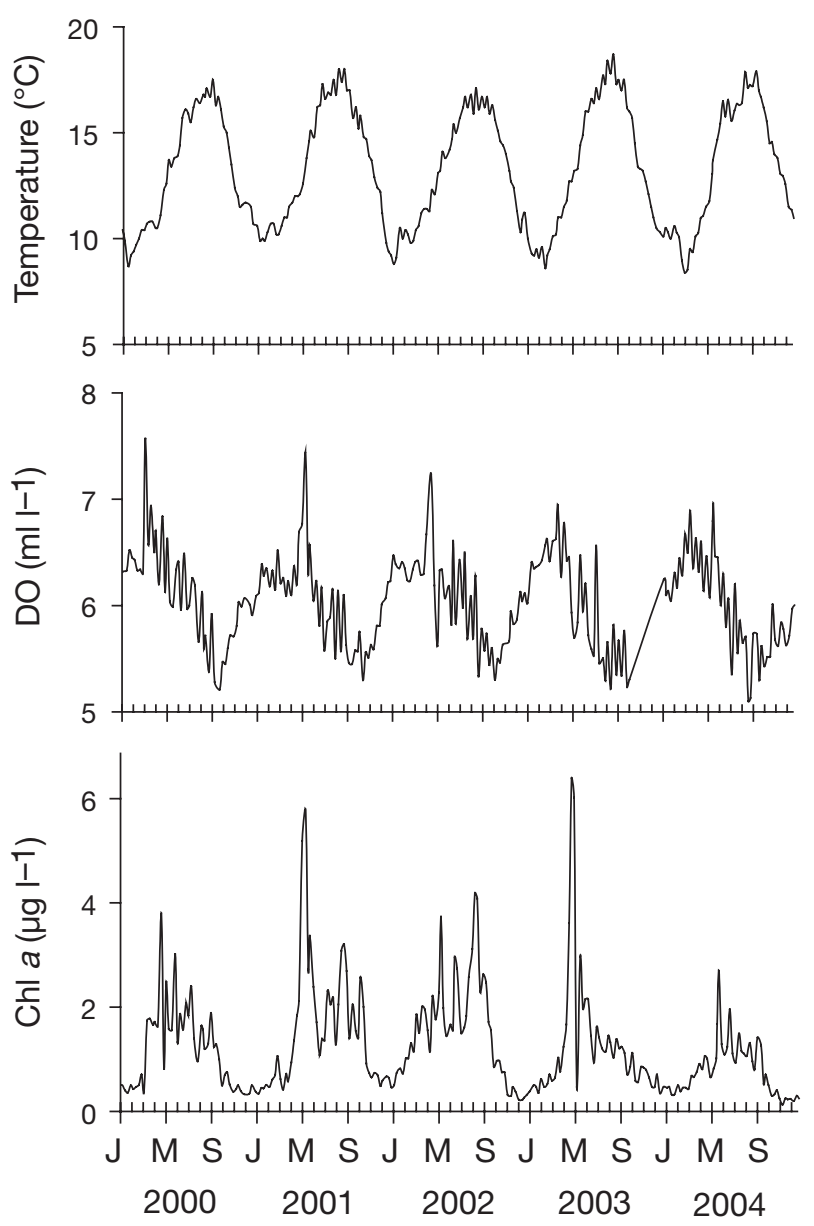

Fig. 2. Evolution of mean values of surface-water temperature, dissolved oxygen (DO), and chl a concentrations recorded at Stn MAREL Iroise for the period from 2000 to 2004 (J: January, M: May, S: September) 
community, representing more than $95 \%$ of the total biomass of calcifying organisms (S. Martin unpubl. data). The rate of calcification by $C$. fornicata was estimated seasonally from size frequency distributions and density measured during the experiments, and from seasonal allometric relationships between shell length and body weight and between body weight and calcification rates reported by Martin et al. (2006). Change in TA from $\mathrm{CaCO}_{3}$ dissolution was neglected, as the dissolution rate of accumulated dead $C$. fornicata shells in the community was estimated to be $<0.1$ uequiv. $\mathrm{d}^{-1} \mathrm{~g}^{-1} \mathrm{DW}$ of shell (S. Martin unpubl. data). Change in TA due to processes other than calcification was expressed as $F^{\prime}{ }_{\mathrm{TA}}=F_{\mathrm{TA}}-F_{\mathrm{TAcalc}}$.

A community respiratory quotient $\left(\mathrm{CRQ}=\mid \mathrm{CR}_{\mathrm{DIC}} /\right.$ $\mathrm{CR}_{\mathrm{DO}}$ |) was established for each season. As DIC release and DO consumption are both affected by natural variability and measurement errors, the community metabolic quotients were calculated by means of functional regressions (Ricker 1973).

The effect of season and station was tested using 1- and 2-way analyses of variance (ANOVA) followed by Newman-Keuls tests. Normal distribution (ShapiroWilks test) and equality of variance (Levene test) were verified prior to analysis. When required, data were log-transformed. The annual estimates of CR at Stns $\mathrm{HD}$ and LD were calculated by summing mean seasonal CR. CR $\mathrm{CR}_{\mathrm{DO}}$ and $\mathrm{CR}_{\mathrm{DIC}}\left(\mathrm{mmol} \mathrm{m}^{-2} \mathrm{~h}^{-1}\right)$ were related to Crepidula fornicata total biomass $\left(\mathrm{g} \mathrm{DW} \mathrm{m}^{-2}\right)$ using linear relationships $(\mathrm{CR}=a \times \mathrm{DW}+b)$ where $a$ and $b$ are coefficients. Covariance analyses (ANCOVAs) were performed to test heterogeneity of $a$ and $b$ coefficients among seasons. Pairwise ANCOVAs were conducted to test significant differences between pairs of seasons. Multiple regression analyses were used to test relationships between $\mathrm{CR}$ and $C$. fornicata biomass, bottom-water temperature, and surface-water chl a concentration. Data were checked for normality and equal variances. To extrapolate our data to carbon fluxes in the whole ecosystem of the Bay of Brest, we considered the average density of $C$. fornicata over the whole area (260 ind. $\mathrm{m}^{-2}$ ) corresponding to a total bio- mass of $668 \mathrm{~g} \mathrm{DW} \mathrm{m}^{-2}$ (Guérin 2004, Martin et al. 2006). To estimate the potential impact of $C$. fornicata proliferation from pre-invasion $\left(0\right.$ ind. $\left.\mathrm{m}^{-2}\right)$ to high proliferation patterns, we also considered the mean density of highly colonized areas (1700 ind. $\mathrm{m}^{-2}$ ), corresponding to $4368 \mathrm{~g} \mathrm{DW} \mathrm{m}^{-2}$ (Ragueneau et al. 2002, Martin et al. 2006). In this case, the daily estimates of CR were calculated monthly from multiple regressions, and the annual estimates of $\mathrm{CR}$ were calculated by summing estimates of monthly CR.

\section{RESULTS}

\section{Environmental parameters and population structure of Crepidula fornicata}

During the experiments, bottom-water temperature, salinity, and DO concentration measured inside the benthic chambers at the beginning of the incubations were similar for the 2 Rozegat stations (Stns HD and LD). Mean $( \pm \mathrm{SD})$ seasonal bottom-water temperature, salinity, DO concentration, and surface-water chl a concentration are presented in Table 2. Sediment comprised $9.3 \pm 2.2 \%$ of organic matter at Stn HD and 5.9 $\pm 1.5 \%$ at Stn LD. The average density of Crepidula fornicata was $1224 \pm 239$ ind. $\mathrm{m}^{-2}$ at Stn HD and $62 \pm$ 77 ind. $\mathrm{m}^{-2}$ at Stn LD, corresponding to a total biomass of $2840 \pm 553$ and $105 \pm 46 \mathrm{~g} \mathrm{DW} \mathrm{m}^{-2}$, respectively. The Stn HD size frequency distribution of the $C$. fornicata population varied seasonally (Fig. 3). The proportion of small (<20 mm shell length) C. fornicata at Stn HD was highest in summer $(25 \%)$ and lowest in spring $(12 \%)$; accordingly, the mean shell length was minimal in summer $(27.4 \pm 9.3 \mathrm{~mm})$ and maximal in spring $(31.1 \pm$ $7.9 \mathrm{~mm})$. The relative frequency of intermediate-sized individuals (20 to $40 \mathrm{~mm}$ ) varied from $70 \%$ in winter to $82 \%$ in autumn, and the proportion of large individuals (>40 mm) varied from $5 \%$ in summer-autumn to $14 \%$ in winter. The proportion of small C. fornicata at Stn LD in summer was $80 \%$, while the proportions of intermediate and large individuals were 16 and $4 \%$,

Table 2. Mean \pm SD seasonal temperature, salinity, and dissolved oxygen (DO) concentration in bottom waters, chl a concentration in surface waters at Stn MAREL Iroise, and Crepidula fornicata density and biomass (DW: dry weight) measured at Stns HD and LD during the chamber experiments

\begin{tabular}{|c|c|c|c|c|c|c|c|c|}
\hline \multirow[t]{2}{*}{ Season } & \multirow[t]{2}{*}{$\begin{array}{c}\text { Temperature } \\
\left({ }^{\circ} \mathrm{C}\right)\end{array}$} & \multirow[t]{2}{*}{$\begin{array}{l}\text { Salinity } \\
\text { (PSU) }\end{array}$} & \multirow[t]{2}{*}{$\begin{array}{c}\mathrm{DO} \\
\left(\mathrm{mg} \mathrm{l}^{-1}\right)\end{array}$} & \multirow[t]{2}{*}{$\begin{array}{l}\text { Chl a } \\
\left(\mu \mathrm{g} \mathrm{l}^{-1}\right)\end{array}$} & \multicolumn{2}{|c|}{$\begin{array}{l}\text { Mean density } \\
\text { (ind. } \mathrm{m}^{-2} \text { ) }\end{array}$} & \multicolumn{2}{|c|}{$\begin{array}{l}\text { Mean biomass } \\
\left(\mathrm{g} \mathrm{DW} \mathrm{m} \mathrm{m}^{-2}\right)\end{array}$} \\
\hline & & & & & $\mathrm{HD}$ & LD & HD & LD \\
\hline Winter & $8.7 \pm 0.1$ & $34.5 \pm 0.1$ & $9.7 \pm 0.3$ & $0.5 \pm 0.0$ & $828 \pm 142$ & $17 \pm 18$ & $1825 \pm 340$ & $47 \pm 46$ \\
\hline Spring & $13.7 \pm 0.4$ & $33.8 \pm 0.4$ & $9.1 \pm 1.1$ & $3.4 \pm 1.8$ & $1351 \pm 367$ & $30 \pm 67$ & $3748 \pm 741$ & $117 \pm 264$ \\
\hline Summer & $17.5 \pm 0.1$ & $36.0 \pm 0.0$ & $8.4 \pm 0.5$ & $1.4 \pm 0.0$ & $1007 \pm 211$ & $177 \pm 133$ & $1839 \pm 321$ & $158 \pm 180$ \\
\hline Autumn & $14.8 \pm 0.3$ & $34.9 \pm 0.1$ & $8.0 \pm 0.2$ & $2.0 \pm 0.8$ & $1790 \pm 309$ & $23 \pm 37$ & $3948 \pm 811$ & $98 \pm 162$ \\
\hline
\end{tabular}


respectively. The mean shell length at Stn LD in summer was thus very low $(11.7 \pm 13.1 \mathrm{~mm})$. The size frequency distributions of the $C$. fornicata population at Stn LD in winter, spring, and autumn were not assessed because of the low numbers of collected individuals $\left(<30\right.$ ind. $\left.\mathrm{m}^{-2}\right)$.

\section{Community respiration}

CR was significantly affected by station (2-way ANOVAs, $F=181.04, \mathrm{p}<0.001$ and $F=106.01, \mathrm{p}<0.001$, for DO and DIC, respectively), being 2-, to 4 -fold higher at Stn HD than at Stn LD, and season (2-way ANOVAs, $F=17.48, \mathrm{p}<0.001$ and $F=22.04, \mathrm{p}<0.001$, for DO and DIC, respectively; Fig. 4). The significant interaction between season and station $(p<0.001)$ showed a different seasonal response depending on the station. At Stn HD, CR varied seasonally (1-way ANOVAs, $F=21.52$, p < 0.001 and $F=38.47$, p $<0.001$, for DO and DIC, respec-

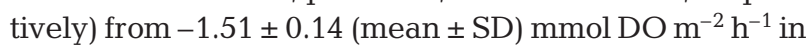

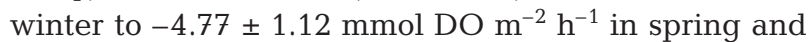
summer, and from $1.47 \pm 0.43 \mathrm{mmol} \mathrm{DIC} \mathrm{m} \mathrm{m}^{-2} \mathrm{~h}^{-1}$ in winter to $5.86 \pm 0.67 \mathrm{mmol}$ DIC m $\mathrm{m}^{-2} \mathrm{~h}^{-1}$ in summer. At Stn LD, $C_{\text {DO }}$ varied significantly according to season (1-way ANOVA, $F=7.16, \mathrm{p}=0.001$ ), with the highest value in summer $\left(-1.63 \pm 0.34 \mathrm{mmol} \mathrm{DO} \mathrm{m}^{-2} \mathrm{~h}^{-1}\right)$, and the lowest between autumn and spring $(-1.00 \pm 0.37 \mathrm{mmol}$ DO $\mathrm{m}^{-2} \mathrm{~h}^{-1}$ ), while $\mathrm{CR}_{\text {DIC }}$ did not differ significantly between seasons, with an overall mean of $1.77 \pm$ $0.39 \mathrm{mmol}$ DIC m${ }^{-2} \mathrm{~h}^{-1}$.

CR was significantly related to Crepidula fornicata biomass, except for DIC fluxes in winter and autumn (Table 3). The rise in CR per biomass unit (a coefficient) increased by a factor of 3 between autumnwinter and spring-summer for DO fluxes and between spring and summer for DIC fluxes. CR without $C$. fornicata ( $b$ coefficient) varied from autumn-winter to summer by a factor of 2 for DO fluxes, but did not differ significantly for DIC fluxes. CR per biomass unit (Fig. 5) varied significantly among seasons (1-way ANOVAs, $F=26.29, \mathrm{p}<0.001$ and $F=82.45, \mathrm{p}<0.001$ for DO and DIC, respectively) from autumn-winter (-0.88 $\mathrm{mmol} \mathrm{DO} \mathrm{g}^{-1} \mathrm{DW} \mathrm{h}^{-1}$ and $0.83 \mathrm{mmol} \mathrm{DIC} \mathrm{g}^{-1} \mathrm{DW}$ $\left.\mathrm{h}^{-1}\right)$ to summer $\left(-2.59 \mathrm{mmol} \mathrm{DO} \mathrm{g}^{-1} \mathrm{DW} \mathrm{h}^{-1}\right.$ and $3.27 \mathrm{mmol} \mathrm{DIC} \mathrm{g}^{-1} \mathrm{DW} \mathrm{h}^{-1}$ ).

$\mathrm{CR}$ was also correlated with temperature $(\mathrm{r}=0.75$, $\mathrm{p}<0.001$ and $\mathrm{r}=0.85, \mathrm{p}<0.001$ for DO and DIC, respectively) and with chl a for DO fluxes ( $r=0.83, p<$ 0.001), but not for DIC fluxes ( $r=0.23, p>0.05)$. Standard multiple regression analysis showed that temperature $(T)$, Crepidula fornicata biomass (DW), and chl a concentration controlled $73 \%$ of $\mathrm{CR}_{\mathrm{DO}}$ data variability, while $T$ and DW controlled $67 \%$ of $\mathrm{CR}_{\mathrm{DIC}}$ data variability:
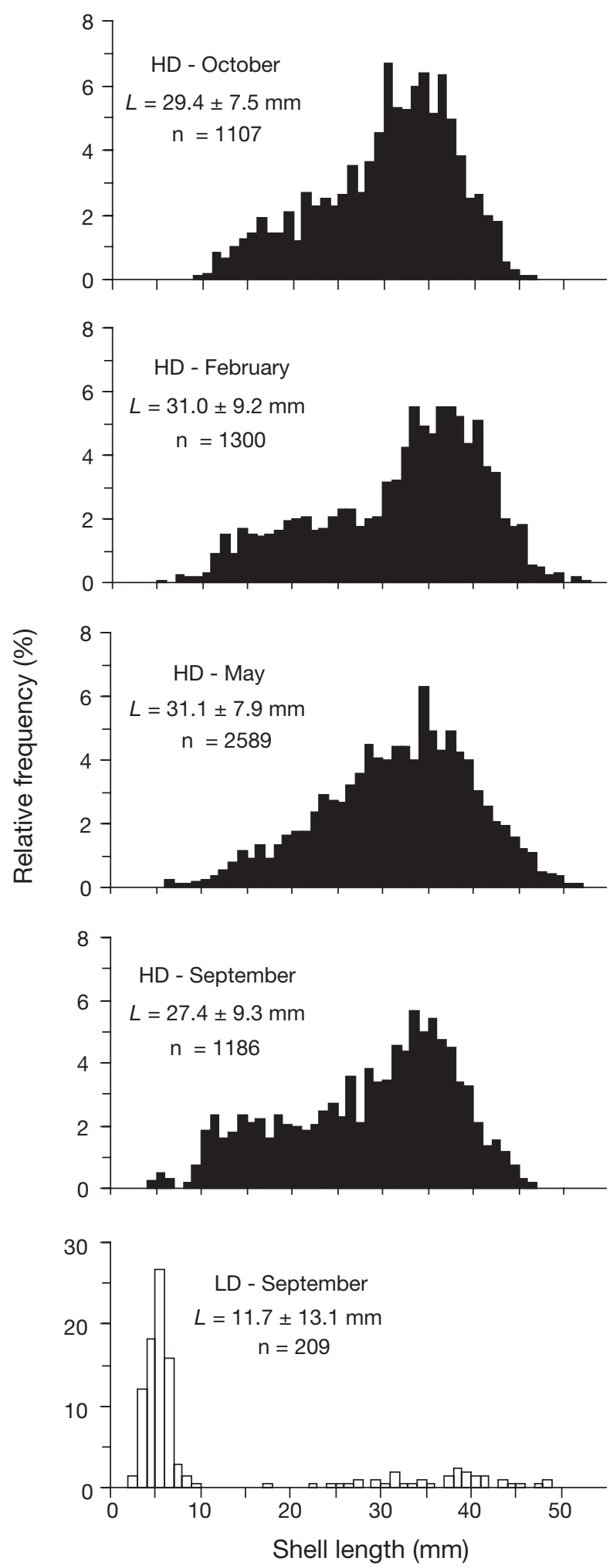

Fig. 3. Crepidula fornicata. Seasonal size frequency distributions of individuals at Sth HD (data from May 2000 and 2001, October 2002, February 2004, and September 2004) and at Stn LD in summer (data from September 2004).

$L$ : mean $( \pm \mathrm{SD})$ shell length; $\mathrm{n}$ : number of observations 


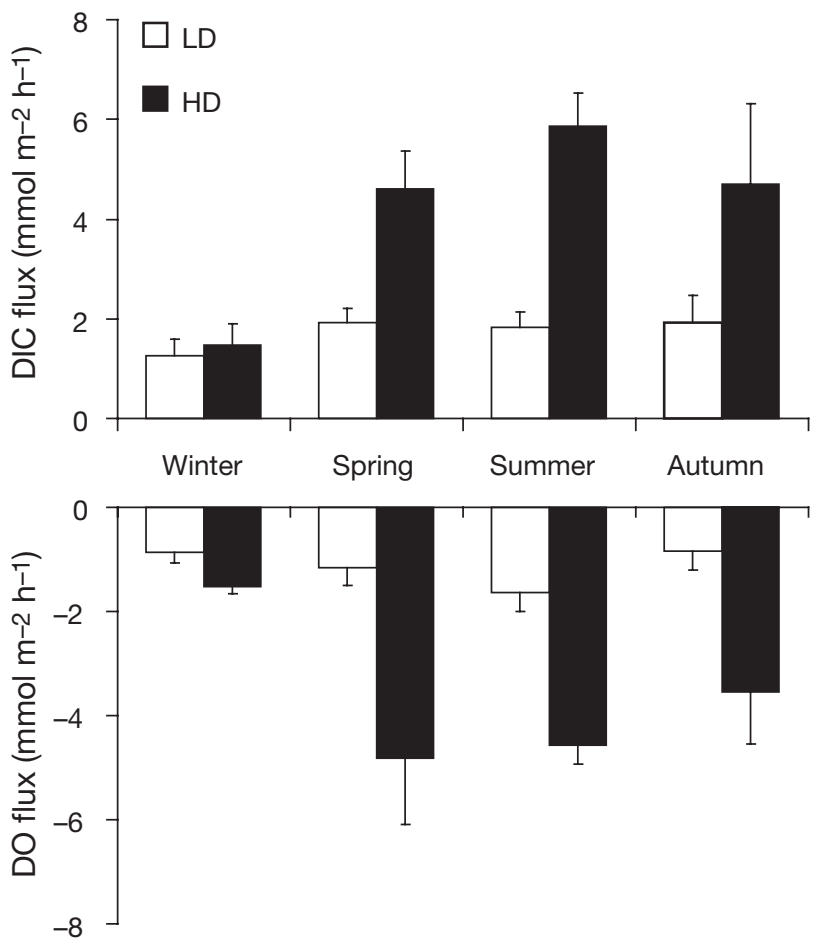

Fig. 4. Seasonal community respiration (mean \pm SD) expressed per surface unit in dissolved inorganic carbon (DIC) release $\left(\mathrm{CR}_{\mathrm{DIC}}\right)$ and dissolved oxygen (DO) consumption $\left(\mathrm{CR}_{\mathrm{DO}}\right)$ at Stns $\mathrm{HD}$ and LD

$$
\begin{gathered}
\mathrm{CR}_{\mathrm{DO}}=0.18 T+0.88 \times 10^{-3} \mathrm{DW}+0.08 \mathrm{chl} \mathrm{T}-1.57 \\
\left(F_{3,68}=60.42, \mathrm{p}<0.001\right) \\
\mathrm{CR}_{\mathrm{DIC}}=0.28 T+0.79 \times 10^{-3} \mathrm{DW}-2.16 \\
\left(F_{2,39}=39.50, \mathrm{p}<0.001\right)
\end{gathered}
$$

In the calculation of $\mathrm{CR}_{\mathrm{DIC}}$ from $F_{\mathrm{DIC}}$ and $F_{\mathrm{TAcal}}$ (Table 4 ), we considered that $F_{\text {TAcalc }}$ was negligible in winter, spring, and autumn at LD because of the low numbers of Crepidula fornicata. $F_{\mathrm{TA}}$ was positive, except in spring at HD. $F^{\prime}$ TA at Stn HD resulting from the difference between $F_{\mathrm{TA}}$ and $F_{\mathrm{TAcalc}}$ was lowest in winter and spring and highest in summer and autumn, being up to 4 -fold higher than at Stn LD.

\section{Community respiratory quotients}

CRQ and intercepts did not differ significantly between winter and spring ( $Z$-test, $Z=0.34, \mathrm{p}=0.63$ and $Z=0.20, p=0.84$, respectively) and between summer and autumn ( $Z$-test, $Z=0.33, \mathrm{p}=0.74$ and $Z=0.77$, $\mathrm{p}=0.44$, respectively). The common CRQ in winterspring was $0.74 \pm 0.24$ (mean $\pm \mathrm{SD}$ ) and was significantly $<1$ ( $Z$-test, $Z=5.27, \mathrm{p}<0.001$ ). The common intercept was $0.49 \pm 0.15 \mathrm{mmol} \mathrm{m}^{-2} \mathrm{~h}^{-1}$ and was signif-
Table 3. Parameter values (SE) calculated by linear regressions of community respiration $\left(\mathrm{CR}_{\mathrm{DO}}\right.$ or $\mathrm{CR}_{\mathrm{DIC}}$ mmol $\mathrm{DO}$ or DIC $\mathrm{m}^{-2} \mathrm{~h}^{-1}$ ) vs. total biomass ( $\mathrm{g} \mathrm{DW} \mathrm{m} \mathrm{m}^{-2}$ ), expressed as $\mathrm{CR}_{\mathrm{DO}}$ (or $\left.\mathrm{CR}_{\mathrm{DIC}}\right)=a \times 10^{-3} \times \mathrm{DW}+b$. Superscripts indicate significant differences between seasons after pairwise comparisons (ANCOVAs; $\mathrm{p}<0.05$ ); nd: no difference; $\mathrm{n}$ : number of observations, $r^{2}$ : proportion of variance explained by the regression, $\mathrm{p}$ : $\mathrm{p}$-value

\begin{tabular}{|lccccc}
\hline Season & $a$ & $b$ & $\mathrm{n}$ & $\mathrm{r}^{2}$ & $\mathrm{p}$ \\
\hline $\mathbf{C R}_{\text {DO }}$ & & & & & \\
Winter & $-0.34^{\mathrm{a}}(0.06)$ & $-0.88^{\mathrm{a}}(0.09)$ & 11 & 0.79 & $<0.001$ \\
Spring & $-1.04^{\mathrm{b}}(0.10)$ & $-1.10^{\mathrm{b}}(0.27)$ & 31 & 0.80 & $<0.001$ \\
Summer & $-1.61^{\mathrm{b}}(0.21)$ & $-1.49^{\mathrm{c}}(0.26)$ & 11 & 0.87 & $<0.001$ \\
Autumn & $-0.68^{\mathrm{a}}(0.07)$ & $-0.82^{\mathrm{a}}(0.19)$ & 18 & 0.83 & $<0.001$ \\
CR $_{\text {DIC }}$ & & & & & \\
Winter & $0.07(0.15)$ & $1.33(0.24)$ & 11 & 0.02 & 0.657 \\
Spring & $0.85^{\mathrm{a}}(0.14)$ & $1.57^{\text {nd }}(0.37)$ & 14 & 0.75 & $<0.001$ \\
Summer & $2.29^{\mathrm{b}}(0.18)$ & $1.57^{\text {nd }}(0.23)$ & 11 & 0.97 & $<0.001$ \\
Autumn & $0.62(0.31)$ & $1.97(1.04)$ & 5 & 0.57 & 0.140 \\
\hline
\end{tabular}

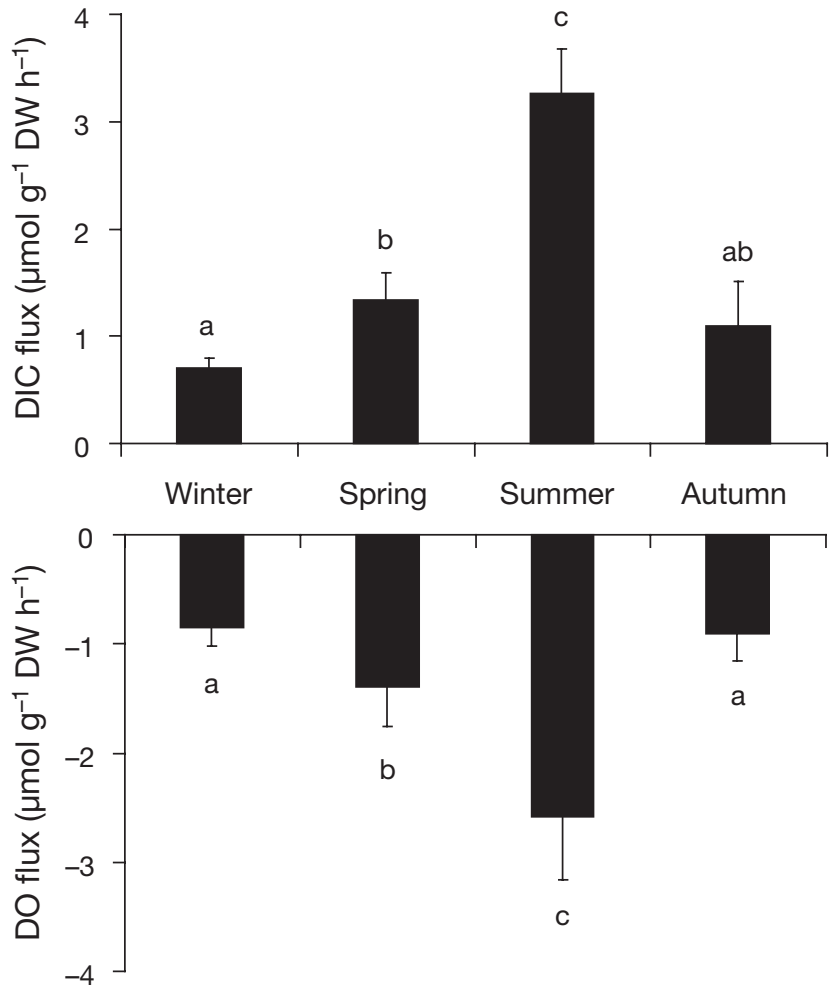

Fig. 5. Seasonal community respiration (mean \pm SD) expressed per biomass unit in DIC release $\left(\mathrm{CR}_{\mathrm{DIC}}\right)$ and DO consumption $\left(\mathrm{CR}_{\mathrm{DO}}\right)$ at $\mathrm{Stn} \mathrm{HD}$. Different letters on bars indicate significant differences among means (Newman-Keuls test, $\mathrm{p}<0.05$ ). DW: dry weight

icantly $>0$ (Z-test, $Z=3.31, \mathrm{p}<0.001)$. The common functional regression explained $90 \%$ of data variability. The common CRQ in summer-autumn was $1.38 \pm$ 0.56 and was significantly $>1$ ( $Z$-test, $Z=2.75, \mathrm{p}=$ 0.01). The common intercept was $-0.16 \pm 0.08 \mathrm{mmol}$ 
Table 4. Mean \pm SD seasonal community DIC fluxes $\left(F_{\mathrm{DIC}}, \mathrm{mmol} \mathrm{m}^{-2} \mathrm{~h}^{-1}\right)$, calculated community respiration $\left(\mathrm{CR}_{\mathrm{DIC}}, \mathrm{mmol} \mathrm{m} \mathrm{m}^{-2} \mathrm{~h}^{-1}\right)$, community total alkalinity (TA) fluxes $\left(F_{\mathrm{TA}}\right.$, mequiv. $\left.\mathrm{m}^{-2} \mathrm{~h}^{-1}\right), \Delta \mathrm{TA}$ from Crepidula fornicata $\mathrm{CaCO}_{3}$ precipitation $\left(F_{\text {TAcalc }}\right.$ mequiv. $\left.\mathrm{m}^{-2} \mathrm{~h}^{-1}\right)$, and $\Delta$ TA due to processes other than calcification $\left(F_{\text {TA, }}^{\prime}\right.$ mequiv. $\left.\mathrm{m}^{-2} \mathrm{~h}^{-1}\right)$. $\Delta$ TA from $C$. fornicata calcification was estimated from seasonal size frequency distributions and densities measured seasonally at $\mathrm{HD}$ and in summer at LD, and from seasonal allometric relationships for C. fornicata calcification reported by Martin et al. (2006)

\begin{tabular}{|lcccrc|}
\hline Season & \multirow{2}{*}{$F_{\mathrm{DIC}}$} & \multicolumn{1}{c}{$\mathrm{CR}_{\mathrm{DIC}}$} & \multicolumn{1}{c}{$F_{\mathrm{TA}}$} & \multicolumn{1}{c|}{$F_{\mathrm{TAcalc}}$} & $F^{\prime}{ }_{\mathrm{TA}}$ \\
\hline HD & & & & & \\
Winter & $1.56 \pm 0.43$ & $1.47 \pm 0.43$ & $0.85 \pm 0.32$ & $0.18 \pm 0.03$ & $0.67 \pm 0.32$ \\
Spring & $4.14 \pm 0.76$ & $4.60 \pm 0.78$ & $-0.32 \pm 0.61$ & $-0.92 \pm 0.11$ & $0.59 \pm 0.63$ \\
Summer & $4.78 \pm 0.47$ & $5.86 \pm 0.67$ & $1.34 \pm 0.38$ & $-2.16 \pm 0.51$ & $3.50 \pm 0.74$ \\
Autumn & $4.08 \pm 1.62$ & $4.69 \pm 1.63$ & $1.59 \pm 0.66$ & $-1.21 \pm 0.06$ & $2.80 \pm 0.68$ \\
LD & & & & & \\
Winter & $1.27 \pm 0.31$ & $1.27 \pm 0.31$ & $0.97 \pm 0.27$ & 0 & $0.97 \pm 0.27$ \\
Spring & $1.93 \pm 0.29$ & $1.93 \pm 0.29$ & $0.76 \pm 0.41$ & 0 & $0.76 \pm 0.41$ \\
Summer & $1.81 \pm 0.30$ & $1.83 \pm 0.30$ & $0.90 \pm 0.59$ & $-0.04 \pm 0.03$ & $0.94 \pm 0.58$ \\
Autumn & $1.92 \pm 0.56$ & $1.92 \pm 0.56$ & $1.25 \pm 1.39$ & 0 & $1.25 \pm 0.97$ \\
\hline
\end{tabular}

$\mathrm{m}^{-2} \mathrm{~h}^{-1}$ and did not differ significantly from zero ( $Z$-test, $Z=0.41, \mathrm{p}=0.69$ ). The common functional regression explained $87 \%$ of data variability.

\section{Carbon budget}

Daily CR measured during our experiments varied seasonally from $0.42 \pm 0.12$ (mean \pm SD) to $1.69 \pm 0.19 \mathrm{~g}$ $\mathrm{C} \mathrm{m}^{-2} \mathrm{~d}^{-1}$ at Stn HD, and from $0.37 \pm 0.09$ to $0.56 \pm$ $0.08 \mathrm{~g} \mathrm{C} \mathrm{m}^{-2} \mathrm{~d}^{-1}$ at Stn LD. Annual CR was estimated to be $437 \pm 92 \mathrm{~g} \mathrm{C} \mathrm{m}^{-2} \mathrm{yr}^{-1}$ at Stn HD and $183 \pm 38 \mathrm{~g} \mathrm{C} \mathrm{m}^{-2}$ $\mathrm{yr}^{-1}$ at Stn LD. Estimated daily CR calculated from multiple linear regression ranged from 1.17 to $1.76 \mathrm{~g} \mathrm{C}$ $\mathrm{m}^{-2} \mathrm{~d}^{-1}$ for a Crepidula fornicata density of 1700 ind. $\mathrm{m}^{-2}$ and from 0.33 to $0.92 \mathrm{~g} \mathrm{C} \mathrm{m}^{-2} \mathrm{~d}^{-1}$ for a density of 260 ind $\mathrm{m}^{-2}$ (Fig. 6). The averaged annual CR was estimated to be $166 \pm 149 \mathrm{~g} \mathrm{C} \mathrm{m}^{-2} \mathrm{yr}^{-1}$ for a null density, $221 \pm 157 \mathrm{~g} \mathrm{C} \mathrm{m}^{-2} \mathrm{yr}^{-1}$ for a density of $260 \mathrm{ind} . \mathrm{m}^{-2}$, and $528 \pm 200 \mathrm{~g} \mathrm{C} \mathrm{m}^{-2} \mathrm{yr}^{-1}$ for a density of 1700 ind. $\mathrm{m}^{-2}$, representing ca. $20 \mathrm{~g} \mathrm{C} \mathrm{m}^{-2} \mathrm{yr}^{-1}$ per 100 ind. $\mathrm{m}^{-2}$ (Fig. 6).

\section{DISCUSSION}

\section{Community respiration and the effect of Crepidula fornicata density}

Crepidula fornicata CR measured in our study at Stn $\mathrm{HD}$ is higher than most rates previously reported for temperate suspension feeder communities (1 to $4 \mathrm{mmol}$ $\mathrm{C} \mathrm{m}^{-2} \mathrm{~h}^{-1}$; Doering et al. 1987, Gibbs et al. 2005, Migné et al. 2005), while CR measured at Stn LD is in agreement with those measured in coastal sediment communities (0.5 to $2 \mathrm{mmol}$ DO or C $\mathrm{m}^{-2} \mathrm{~h}^{-1}$; Cook et al. 2004, Gibbs et al. 2005) and in the lowest range of those reported for organic matter enriched sediments impacted by shellfish cultures ( 1 to $4 \mathrm{mmol} \mathrm{DO} \mathrm{m}{ }^{-2} \mathrm{~h}^{-1}$; Hatcher et al. 1994, Mazouni et al. 1996, Thouzeau et al. 2007).

Large differences in CR were observed between stations with high (Stn HD) and low (Stn LD) Crepidula fornicata densities from spring to autumn, which were 2- to 4 -fold higher at Stn HD than at Stn LD. In winter, CR at Stn HD was only 1.5-fold higher than at Stn LD. Differences in CR between sites are related to $C$. fornicata biomass, as illustrated by the strong positive linear relationships between biomass and CR. The small difference in CR between Stns HD and LD in winter may be explained by a reduction in $C$. fornicata respiration rate when temperature decreases (Martin et al. 2006). C. fornicata respiration at Stn HD, estimated from allometric relationships (Martin et al. 2006; Table 5), accounts for
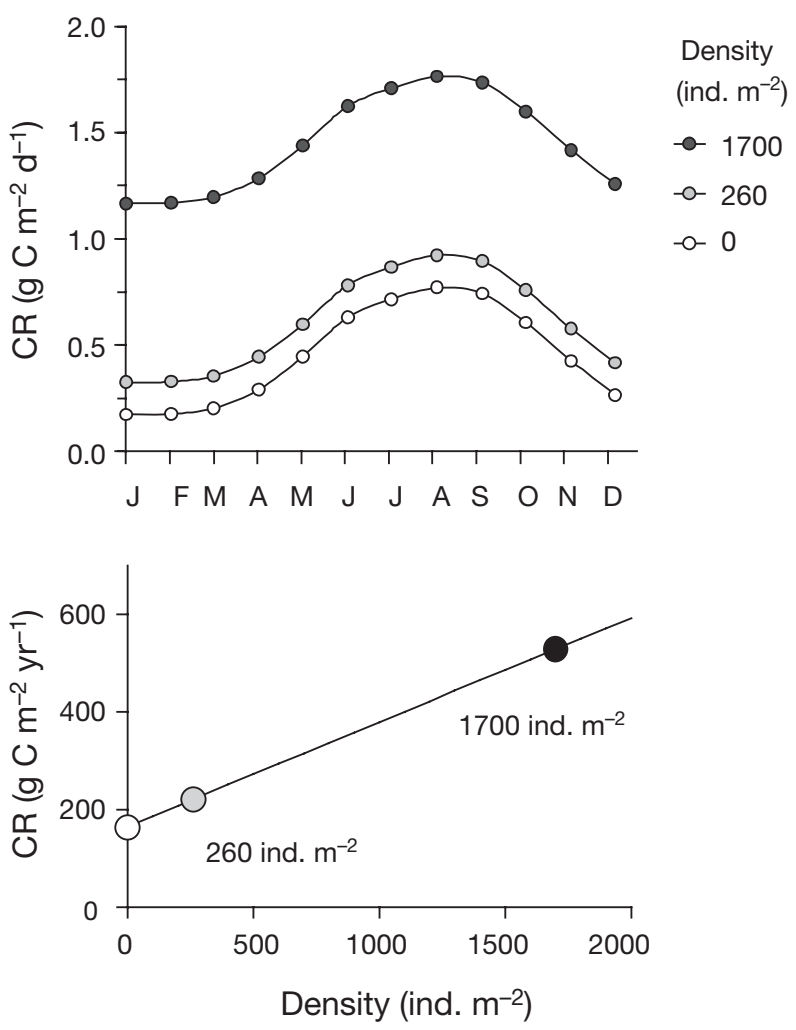

Fig. 6. Evolution of estimated daily community respiration (CR) in sites displaying densities of 0,260 , and 1700 ind. $\mathrm{m}^{-2}$, and estimation of annual CR vs. Crepidula fornicata density 
ca. $30 \%$ of $\mathrm{CR}$ in winter versus 40 to $60 \%$ from spring to autumn. Accordingly, sediment respiration without $C$. fornicata ( $b$ coefficient, Table 3 ) accounts for $90 \%$ of $\mathrm{CR}$ in winter and 30 to $40 \%$ from spring to autumn at Stn HD.

The accumulation of organic matter from Crepidula fornicata biodeposition also enhances oxygen consumption rates and potentially limits oxygen penetration in the sediments (Christensen et al. 2003). The resulting anaerobic environment under the sediment surface promotes ammonification and sulfate reduction (Rowe et al. 2002). Accordingly, measured community TA changes $\left(F_{\mathrm{TA}}\right)$ were positive, except in spring at Stn HD, indicating that processes increasing TA (ammonification, $\Delta \mathrm{TA}=+2$ equiv. and sulfate reduction, $\Delta \mathrm{TA}=+2$ equiv.) were predominant in the community. TA fluxes due to these processes $\left(F^{\prime}{ }_{\mathrm{TA}}\right)$ were up to 4 -fold higher at Stn HD than at Stn LD, reflecting higher ammonification and sulfate reduction rates where biodeposition was enhanced. The increase of $F^{\prime}$ TA in summer-autumn at Stn HD is also consistent with the DO depletion in the water column and the high metabolism (respiration and biodeposition) of $C$. fornicata during this period.

In this study, a comparison of CR using contrasting densities of Crepidula fornicata was performed at 2 different stations. Since we do not have any information on the environmental variability of CR between stations, even if they are located nearby, further investigations on spatial variability of $\mathrm{CR}$ are required to improve our knowledge of the effect of $C$. fornicata density on CR.

\section{Environmental factors regulating community respiration}

CR showed a distinct seasonal pattern primarily related to water temperature, as illustrated by the strong positive relationships between temperature and respiration. Such a coupling between temperature and sediment respiration rates has been well documented (Doering et al. 1987, Hatcher et al. 1994, Eyre \& Ferguson 2005). The influence of organic matter sedimentation from the water column on sediment respiration is also well established (Banta et al. 1995, Rysgaard et al. 1998). Chl a concentration in the water column positively influenced $\mathrm{CR}_{\mathrm{DO}}$. Chl a concentration is an indicator of phytoplankton biomass in the water column and reflects the delivery of fresh organic matter to the sediments (Stenton-Dozey et al. 2001, Eyre \& Ferguson 2005). The feeding activities of $C$. fornicata (filtration + biodeposition) are also related to phytoplankton biomass, as well as the subsequent biodeposit remineralization (Stenton-Dozey et al. 2001). Accordingly, CR in spring is clearly enhanced by the delivery of organic matter from the phytoplanktonic bloom that occurs in May in the Bay of Brest. Despite low spring temperature $\left(14^{\circ} \mathrm{C}\right), \mathrm{CR}$ in this season was about 1.5-fold higher than that in autumn $\left(15^{\circ} \mathrm{C}\right)$ and was similar to that observed in summer $\left(17.5^{\circ} \mathrm{C}\right)$. There was also a seasonal pattern in CRQ, with $\mathrm{CRQ}<1$ in winter-spring but $>1$ in summerautumn. CRQ $<1$ occurs when accumulated reduced equivalents are oxidized, while CRQ $>1$ occurs when reduced equivalents are stored, most likely because of enhanced carbon decomposition through sulfate reduction (Eyre \& Ferguson 2005). CRQ $>1$ in summerautumn is consistent with the increase of $F^{\prime}$ TA in summer-autumn indicating sulfate reduction processes.

\section{Implication of Crepidula fornicata invasion on carbon budget in impacted areas}

The invasive species Crepidula fornicata affects community metabolism and thus induces changes in carbon cycling. Through respiration and feeding activities, $C$. fornicata proliferation enhances $p \mathrm{CO}_{2}$ in seawater and may contribute to the release of $\mathrm{CO}_{2}$ to the atmosphere. The respiration of the other components of the community, micro-, meio- and macroorganisms, also contributes to the increase of $p \mathrm{CO}_{2}$ in seawater. $\mathrm{CR}$ in sites with high $C$. fornicata densities (530 $\mathrm{g} \mathrm{C} \mathrm{m}^{-2} \mathrm{yr}^{-1}$ ) falls within the highest range of values reported for communities displaying high mollusk densities (230 to $600 \mathrm{~g} \mathrm{C} \mathrm{m}^{-2} \mathrm{yr}^{-1}$; see review by Chauvaud et al. 2003). Carbon release from CR estimated for the mean C. fornicata density (260 ind. $\mathrm{m}^{-2}$ ) is higher than carbon uptake from phytoplanktonic (148 $\mathrm{g} \mathrm{C} \mathrm{m}^{-2} \mathrm{yr}^{-1}$; Del Amo 1996) and microphytobenthic (20 to $40 \mathrm{~g} \mathrm{C} \mathrm{m}^{-2} \mathrm{yr}^{-1}$; Ni Longphuirt 2006) produc-

Table 5. Crepidula fornicata. Mean \pm SD seasonal respiration $\left(\mathrm{mmol} \mathrm{DIC} \mathrm{m}^{-2} \mathrm{~h}^{-1}\right.$ ) of the population and differences with total benthic community respiration at Stn HD. Percentage of C. fornicata respiration in the community is also given. Respiration of the $C$. fornicata population was estimated per $\mathrm{m}^{2}$ from seasonal size frequency distributions and densities measured at Stn HD, and from seasonal allometric relationships between $C$. fornicata shell length and body weight and between body weight and respiration rates reported by Martin et al. (2006)

\begin{tabular}{|lccc|}
\hline Season & C. fornicata respiration & Difference & $\%$ \\
\hline Winter & $0.49 \pm 0.20$ & $0.98 \pm 0.63$ & 33 \\
Spring & $2.81 \pm 1.08$ & $1.79 \pm 1.86$ & 61 \\
Summer & $2.48 \pm 0.83$ & $3.38 \pm 1.50$ & 42 \\
Autumn & $2.90 \pm 0.94$ & $1.78 \pm 2.57$ & 62 \\
\hline
\end{tabular}


tion in the Bay of Brest, suggesting a net increase of $p \mathrm{CO}_{2}$ in seawater, and thus a possible efflux of $\mathrm{CO}_{2}$ to the atmosphere. Considering the whole surface of the Bay of Brest $\left(180 \mathrm{~km}^{2}\right)$, the proliferation of C. fornicata since the pre-invasion, $50 \mathrm{yr}$ ago, to the present situation has increased carbon release by a factor of 1.5 , corresponding to 10000 tons $\mathrm{C} \mathrm{yr}^{-1}$. Considering a potential scenario of a total colonization of the bay by C. fornicata at ca. 1700 ind. $\mathrm{m}^{-2}$, the additional carbon release in seawater since the pre-invasion may be up to $5 \mathrm{Gmol} \mathrm{C} \mathrm{yr}^{-1}$, corresponding to 65000 tons $\mathrm{C} \mathrm{yr}^{-1}$. In addition, $\mathrm{CO}_{2}$ released by calcification may enhance the given values of calculated community carbon production by $10 \%$ if we consider that carbon release by $C$. fornicata shell calcification represents $20 \%$ of carbon release by $C$. fornicata respiration (Martin et al. 2006), the latter corresponding to ca. $50 \%$ of carbon release by CR. Thus, the impact of $C$. fornicata must not be considered only at population or community levels (De Montaudouin \& Sauriau 1999, Chauvaud et al. 2000, Thouzeau et al. 2000), but also in terms of the carbon source, especially in a context of global change.

Acknowledgements. We thank C. Poulain, A. Maltot, and A. Michel for laboratory assistance and J. Richard, E. Amice, and R. Marc for diving and for their help at sea. We are also grateful to A. Masson for valuable technical assistance and to the Service d'Observation en Milieu LITtoral (SOMLIT, INSU CNRS) group for providing data from the MAREL Iroise station.

\section{LITERATURE CITED}

Arnott DL, Vanni MJ (1996) Nitrogen and phosphorus recycling by the zebra mussel (Dreissena polymorpha) in the western basin of Lake Erie. Can J Fish Aquat Sci 53: 646-659

Banta G, Giblin AE, Hobbie JE, Tucker J (1995) Benthic respiration and nitrogen release in Buzzards Bay, Massachusetts. J Mar Res 53:107-135

Blanchard M (1997) Spread of the slipper limpet Crepidula fornicata (L. 1758) in Europe. Current state and consequences. Sci Mar 61:109-118

Carlton JT, Thompson JK, Schemel LE, Nichols FH (1990) Remarkable invasion of San Francisco Bay (California, USA) by the Asian clam Potamocorbula amurensis. I. Introduction and dispersal. Mar Ecol Prog Ser 66:81-94

Chauvaud L, Jean F, Ragueneau O, Thouzeau G (2000) Longterm variation of the Bay of Brest ecosystem: benthic-pelagic coupling revisited. Mar Ecol Prog Ser 200:35-48

Chauvaud L, Thompson JK, Cloern JE, Thouzeau G (2003) Clams as $\mathrm{CO}_{2}$ generators: the Potamocorbula amurensis example in San Francisco Bay. Limnol Oceanogr 48: 2086-2092

Chisholm JRM, Gattuso JP (1991) Validation of the alkalinity anomaly technique for investigating calcification and photosynthesis in coral reef communities. Limnol Oceanogr 36:1231-1239

Christensen PB, Glud RN, Dalsgaard T, Gillespie P (2003) Impacts of longline mussel farming on oxygen and nitrogen dynamics and biological communities of coastal sedi- ments. Aquaculture 218:567-588

Cook PLM, Butler ECV, Eyre BD (2004) Carbon and nitrogen cycling on intertidal mudflats of a temperate Australian estuary. I. Benthic metabolism. Mar Ecol Prog Ser 280: $25-38$

Dame RF (1996) Ecology of marine bivalves: an ecosystem approach. CRC Press, Boca Raton, FL

Del Amo Y (1996) Dynamique et structure des communautés phytoplanctoniques en écosystème côtier perturbé: Cinétiques de l'incorporation du silicium par les diatomées. $\mathrm{PhD}$ thesis, Université de Bretagne Occidentale, Brest

De Montaudouin X, Sauriau PG (1999) The proliferating Gastropoda Crepidula fornicata may stimulate macrozoobenthic diversity. J Mar Biol Assoc UK 79:1069-1077

DOE (Department of Energy 1994) Dickson AG, Goyet C (eds) Handbook of methods for the analysis of the various parameters of the carbon dioxide system in sea water; version 2. Tech Rep ORNL/CDIAC-74, Oak Ridge National Laboratory, Oak Ridge, TN

Doering PH, Kelly JR, Oviatt CA, Sowers T (1987) Effect of the hard clam Mercenaria mercenaria on benthic fluxes of inorganic nutrients and gases. Mar Biol 94:377-383

Eyre BD, Ferguson AJP (2005) Benthic metabolism and nitrogen cycling in a subtropical east Australian estuary (Brunswick): temporal variability and controlling factors. Limnol Oceanogr 50:81-96

Gattuso JP, Frankignoulle M, Smith SV (1999) Measurement of community metabolism and significance in the coral reef $\mathrm{CO}_{2}$ source-sink debate. Proc Natl Acad Sci USA 96: $13017-13022$

Gibbs M, Funnell G, Pickmere S, Norkko A, Hewitt J (2005) Benthic nutrient fluxes along an estuarine gradient: influence of the pinnid bivalve Atrina zelandica in summer. Mar Ecol Prog Ser 288:151-164

Grosholz E (2002) Ecological and evolutionary consequences of coastal invasions. Trends Ecol Evol 17:22-27

Guérin L (2004) La crépidule en rade de Brest: un modèle biologique d'espèce introduite proliférante en réponse aux fluctuations de l'environnement. $\mathrm{PhD}$ thesis, Université de Bretagne Occidentale, Brest

Hatcher A, Grant J, Schofield B (1994) Effects of suspended mussel culture (Mytilus spp.) on sedimentation, benthic respiration and sediment nutrient dynamics in a coastal bay. Mar Ecol Prog Ser 115:219-235

Lewis E, Wallace DWR (1998) Program developed for $\mathrm{CO}_{2}$ system calculations. ORNL/CDIAC-105. Carbon Dioxide Information Analysis Center, Oak Ridge National Laboratory, US Department of Energy, Oak Ridge, TN

Mack RN, Simberloff D, Lonsdale WM, Evans H, Clout M, Bazzaz FA (2000) Biotic invasions: causes, epidemiology, global consequences, and control. Ecol Appl 10:689-710

Martin S, Clavier J, Guarini JM, Chauvaud L and 5 others (2005) Comparison of Zostera marina and maerl community metabolism. Aquat Bot 83:161-174

Martin S, Thouzeau G, Chauvaud L, Jean F, Guérin L, Clavier J (2006) Respiration, calcification and excretion of the invasive species, Crepidula fornicata L.: implications for carbon, carbonate and nitrogen fluxes in affected areas. Limnol Oceanogr 51:1996-2007

Mazouni N, Gaertner JC, Deslous-Paoli JM, Landrein S, Geringer d'Oedenberg M (1996) Nutrient and oxygen exchanges at the water-sediment interface in a shellfish farming lagoon (Thau, France). J Exp Mar Biol Ecol 205:91-113

Middelburg JK, Duarte CM, Gattuso JP (2005) Respiration in coastal benthic communities. In: del Giorgio PA, Williams PJB (eds) Respiration in aquatic ecosystems. Oxford University Press, New York, p 206-224 
Migné A, Davoult D, Bourrand JJ, Boucher G (2005) Benthic primary production, respiration and remineralisation: in situ measurements in the soft-bottom Abra alba community of the western English Channel (North Brittany). J Sea Res 53:223-229

Mills EL, Leach JH, Carlton JT, Secor CL (1993) Exotic species in the Great Lakes: a history of biotic crises and anthropogenic introductions. J Gt Lakes Res 19:1-54

Ni Longphuirt S (2006) Rôle du microphytobenthos dans le cycle du silicium et le fonctionnement d'un écosystème côtier: La rade de Brest. PhD thesis, Université de Bretagne Occidentale, Brest

Ragueneau O, Chauvaud L, Leynaert A, Thouzeau G and 8 others (2002) Direct evidence of a biologically active coastal silicate pump: ecological implications. Limnol Oceanogr 47:1849-1854

Ragueneau O, Chauvaud L, Moriceau B, Leynaert A, Thouzeau G, Donval A, Le Loc'h F, Jean F (2005) Biodeposition by an invasive suspension feeder impacts the biogeochemical cycle of $\mathrm{Si}$ in a coastal ecosystem (Bay of Brest, France). Biogeochemistry 75:19-41

Ricker WE (1973) Linear regression in fishery research. J Fish Res Board Can 30:409-434

Rowe GT, Cruz-Kaegia ME, Morse JW, Boland GS, Escobar Briones EG (2002) Sediment community metabolism asso-

Editorial responsibility: Howard Browman (Associate Editorin-Chief), Storebø, Norway ciated with continental shelf hypoxia, northern Gulf of Mexico. Estuaries 25:1097-1106

Rysgaard S, Thamdrup B, Risgaard-Petersen N, Fossing H, Berg P, Christensen PB, Dalsgaard T (1998) Seasonal carbon and nutrient mineralisation in a high-Arctic coastal marine sediment, Young Sound, Northeast Greenland. Mar Ecol Prog Ser 175:261-276

Stachowicz JJ, Byrnes JE (2006) Species diversity, invasion success, and ecosystem functioning: disentangling the influence of resource competition, facilitation, and extrinsic factors. Mar Ecol Prog Ser 311:251-262

Stenton-Dozey J, Probyn T, Busby A (2001) Impact of mussel (Mytilus galloprovincialis) raft-culture on benthic macrofauna, in situ oxygen uptake, and nutrient fluxes in Saldanha Bay, South Africa. Can J Fish Aquat Sci 58: 1021-1031

Thouzeau G, Chauvaud L, Grall J, Guérin L (2000) Rôle des interactions biotiques sur le devenir du pré-recrutement et la croissance de Pecten maximus (L.) en rade de Brest. C R Acad Sci Serie III Sci Vie 323:815-825

Thouzeau G, Grall J, Clavier J, Chauvaud L and 5 others (2007) Spatial and temporal variability of benthic biogeochemical fluxes associated with macrophytic and macrofaunal distributions in the Thau lagoon (France). Estuar Coast Shelf Sci 72(3):432-447

Submitted: June 30, 2006; Accepted: March 29, 2007 Proofs received from author(s): September 21, 2007 